\title{
Investigation of Possible Effect of Calcium Carbimide on Urinary Oxalate Excretion in Primary Hyperoxaluria
}

\author{
DOROTHY A. GIBBS and R. W. E. WATTS \\ From the Medical Professorial Unit (Dunn Laboratories), St. Bartholomew's Hospital, London
}

We recently investigated the possibility of reducing the increased urinary oxalate excretion in primary hyperoxaluria by inhibiting some of the enzymes that catalyse the oxidation of aldehydes to carboxylic acids. Disulfiram (tetraethylthiuram disulphide), which inhibits aldehyde dehydrogenase (aldehyde: NAD oxidoreductase (EC 1.2.1.3.)), was among the substances studied and found to be ineffective (Gibbs and Watts, 1967). Solomons, Goodman, and Riley (1967) subsequently reported that calcium carbimide ${ }^{\star}$ (calcium cyanamide), which also inhibits aldehyde dehydrogenase, reduced the urinary oxalate excretion in a patient with primary hyperoxaluria. Their patient had recently received a cadaver kidney transplant because of renal failure associated with calcium oxalate nephrocalcinosis, and they suggested that calcium carbimide might be used prophylactically to reduce the urinary oxalate excretion and prevent renal damage in the disease.

This communication reports an investigation of the effect of calcium carbimide on the urinary oxalate excretion by a patient with primary hyperoxaluria who had good over-all renal function and no detectable calculi or nephrocalcinosis when he was studied.

\section{Case Report and Methods}

The patient was a 10-year-old-boy who had presented with haematuria when he was 1 year old. Calculi were removed from the left kidney when he was $2 \frac{1}{2}$ years old, and urinary infections and haematuria occurred intermittently between the ages of 2 and 4 years. He passed a calculus per urethram when he was 7 years old, but had been asymptomatic except for occasional slight abdominal pain since then. His height and weight were at approximately the 50th centile $(137 \mathrm{~cm}$. and $28.6 \mathrm{~kg}$., respectively), and the results of physical

\footnotetext{
Received October 17, 1967.

* Calcium carbimide is marketed under the trade name 'Temposil' by Lederle Laboratories Ltd., London.
}

examination were normal except for a mild pectus excavatus deformity and the healed left nephrolithotomy scar. Blood pressure, $90 / 65 \mathrm{~mm}$. Hg. Urine contained no protein or glucose, and urinary centrifuge deposit was normal and sterile. Blood urea, $36 \mathrm{mg} . / 100 \mathrm{ml}$.; inulin clearance, $102 \mathrm{ml} . / \mathrm{min} .1 \cdot 73 \mathrm{~m}^{2}$; para-aminohippurate (PAH) clearance, $572 \mathrm{ml} . / \mathrm{min} .1 \cdot 73 \mathrm{~m}^{2}$; urinary amino acid excretion normal (examined qualitatively by thinlayer chromatography, and by quantitative ion exchange chromatography with a Technicon amino acid analyser (Technicon Instruments Ltd., Chertsey, Surrey)), and this agrees with previous observations (Gibbs, Thompson, and Watts, 1967). Urinary acidification normal by short test of urinary acidification of Wrong and Davies (1959). There were no calcium oxalate crystals in the sternal marrow and no calculi or nephrocalcinosis detectable on plain abdominal $x$-rays or on intravenous pyelography.

The patient was in hospital but fully ambulant during the present studies, and he took a repetitive diet which provided a calculated intake of $56 \mathrm{~g}$. protein, $105 \mathrm{~g}$. fat, $322 \mathrm{~g}$. carbohydrate, $12 \mathrm{mg}$. ascorbic acid, $26 \mathrm{mg}$. oxalic acid, and 2414 calories per 24 hours. The diet was self selected and similar to that which the patient ate at home, and the present observations were not begun until such minor changes as were necessary to ensure that all the food would be eaten every day had been made.

Urine collections were made as described previously (Gibbs and Watts, 1967). The urinary oxalate content was measured by isotope dilution analysis also as described previously (Dean and Griffin, 1965; Gibbs and Watts, 1966), except that the oxalate was extracted by shaking with tri-n-butylorthophosphate $(375 \mathrm{ml}$. tri-n-butylorthophosphate to $750 \mathrm{ml}$. urine to which $42 \mathrm{ml}$. of approximately $18 \mathrm{~N}$ sulphuric acid had been added) at room temperature instead of hot ether. Creatinine was measured by the method of Peters and Van Slyke (1932).

\section{Results}

Calcium carbimide did not reduce the urinary oxalate excretion in this study (Fig. and Table). The two pretreatment control periods were separated by a period of 30 days during which the subject 


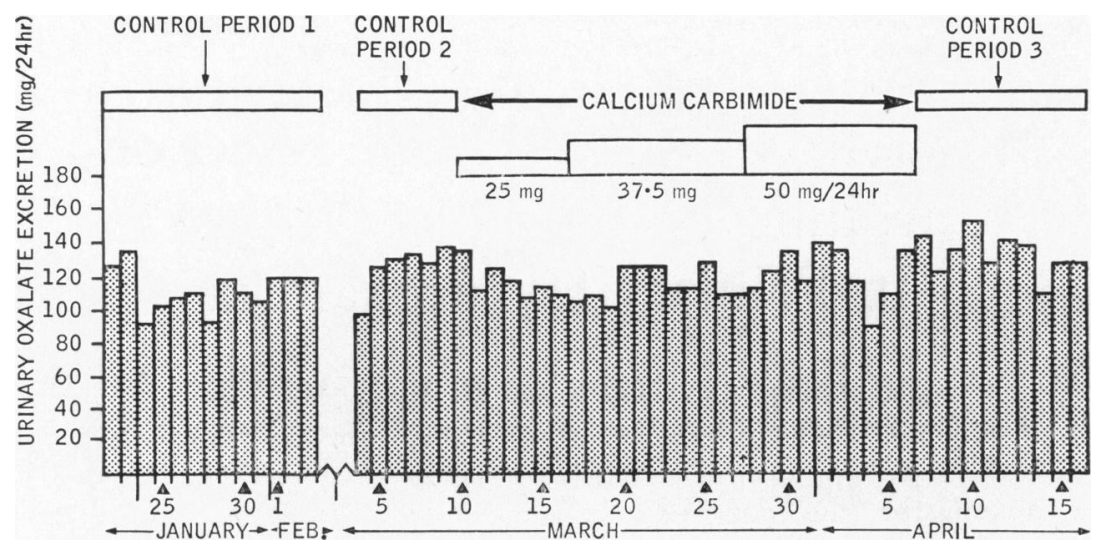

FIG.-Urinary oxalate excretion during calcium carbimide therapy and during the control periods.

TABLE

Urinary Oxalate Excretion and Calcium Carbimide Administration

\begin{tabular}{|c|c|c|c|c|c|c|c|}
\hline \multirow{3}{*}{ Régime } & \multirow{3}{*}{$\begin{array}{c}\text { Duration } \\
\text { (day) }\end{array}$} & \multicolumn{6}{|c|}{ Oxalate Excretion * } \\
\hline & & \multicolumn{3}{|c|}{ mg. $/ 24 \mathrm{hr}$. } & \multicolumn{3}{|c|}{ mg./mg. creatinine } \\
\hline & & Range & Mean & $\begin{array}{l}\text { Standard } \\
\text { Deviation }\end{array}$ & Range & Mean & $\begin{array}{l}\text { Standard } \\
\text { Deviation }\end{array}$ \\
\hline 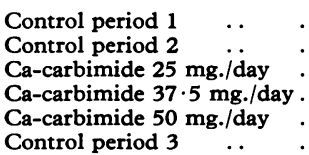 & $\begin{array}{r}13 \\
6 \\
7 \\
11 \\
10 \\
10\end{array}$ & $\begin{array}{r}92-136 \\
95-136 \\
105-135 \\
101-126 \\
90-137 \\
118-153\end{array}$ & $\begin{array}{l}112 \\
123 \\
116 \\
112 \\
119 \\
133\end{array}$ & $\begin{array}{r}13 \\
15 \\
10 \\
9 \\
15 \\
11\end{array}$ & $\begin{array}{l}0 \cdot 094-0 \cdot 163 \\
0 \cdot 132-0 \cdot 162 \\
0 \cdot 114-0 \cdot 176 \\
0 \cdot 130-0 \cdot 156 \\
0 \cdot 075-0 \cdot 165 \\
0 \cdot 134-0 \cdot 183\end{array}$ & $\begin{array}{l}0 \cdot 136 \\
0 \cdot 150 \\
0 \cdot 140 \\
0 \cdot 141 \\
0 \cdot 136 \\
0 \cdot 159\end{array}$ & $\begin{array}{l}0.020 \\
0.011 \\
0.019 \\
0.032 \\
0.026 \\
0.017\end{array}$ \\
\hline
\end{tabular}

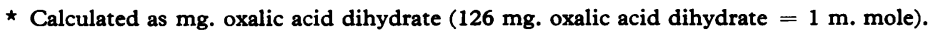

took the same diet, but other measures aimed at reducing his urinary oxalate excretion were being investigated. The results obtained in the three control periods do not differ significantly from one another.

\section{Discussion}

The urinary oxalate excretion in primary hyperoxaluria varies appreciably from day to day, even under closely controlled conditions and when renal structure and function remain apparently normal. The terminal phase of the illness, in which the rate of calcium oxalate deposition in the kidney probably increases, is associated with very wide day-to-day fluctuations in the urinary oxalate excretion (Watts, 1960). It is possible that calcium oxalate was being deposited intermittently in the transplanted kidneys during the study of Solomons et al. (1967), so that the apparent association of diminished oxalate excretion and drug administration which they observed was fortuitous, and this would have been revealed by more prolonged studies. Oxalate is excreted by glomerular filtration and by tubular transport mechanisms (Cattell et al., 1962), and the ability of transplanted kidneys, which have presumably suffered some degree of immunological damage, to excrete oxalate is uncertain and may not be completely stable.

It is, however, possible that the discrepancy between the present findings and those of Solomons et al. (1967) is a further indication that primary hyperoxaluria may be due to two or more biochemical entities, only one of which requires normal aldehyde dehydrogenase activity to maintain the high level of urinary oxalate excretion which is characteristic of the disease. Williams, Koch, and Smith (1967) have also suggested that primary hyperoxaluria is a heterogeneous condition on the basis of their observation that glyceric aciduria occurs in some patients with the disease but not in others. Shepard, 


\section{Possible Effect of Calcium Carbimide on Urinary Oxalate Excretion in Primary Hyperoxaluria 315}

Lee, and Krebs (1960) reported a family in which the disease appeared to have a dominant pattern of inheritance as opposed to the usual recessive pattern (Scowen, Watts, and Hall, 1959), suggesting genetic as well as biochemical heterogeneity in the disease.

\section{Summary}

Calcium carbimide did not reduce the urinary oxalate excretion in a patient with primary hyperoxaluria who had no evidence of structural or functional renal impairment. The possible significance of this observation is discussed in the light of a previous report to the contrary from another laboratory.

We are pleased to acknowledge our indebtedness to Dr. A. D. M. Jackson who referred the patient to R.W.E.W. We are also indebted to Professor E. F. Scowen for his continued interest in this topic, to $\mathrm{Mr}$. L. A. Rawlings for his help, and to the dietitians and nurses attached to the metabolic ward of the hospital for their painstaking work. These investigations were generously supported financially by the Board of Governors of St. Bartholomew's Hospital.

\section{REFERENCES}

Cattell, W. R., Spencer, A. G., Taylor, G. W., and Watts, R. W. E. (1962). The mechanism of the renal excretion of oxalate in the dog. Clin. Sci., 22, 43.

Dean, B. M., and Griffin, W. J. (1965). Estimation of urinary oxalate by the method of isotope dilution. Nature (Lond.), 205, 598.

Gibbs, D. A., Thompson, C. J., and Watts, R. W. E. (1967). Plasma and urinary amino acids in children with primary hyperoxaluria and in normal children. Arch. Dis. Childh., 42, 619.

C, and Watts, R. W. E. (1966). An investigation of the possible role of xanthine oxidase in the oxidation of glyoxylate to oxalate. Clin. Sci., 31, 285.

-, and - (1967). Biochemical studies on the treatment of primary hyperoxaluria. Arch. Dis. Childh., 42, 505.

Peters, J. P., and Van Slyke, D. D. (1932). Quantitative Clinical Chemistry, Vol. 2, p. 602. Williams and Wilkins, Baltimore.

Scowen, E. F., Watts, R. W. E., and Hall, E. G. (1959). Further observations on the genetic basis of primary hyperoxaluria. Ann. hum. Genet., 23, 367.

Shepard, T. H., Lee, L. W., and Krebs, E. G. (1960). Primary hyperoxaluria. II. Genetic studies in a family. Pediatrics, $25,869$.

Solomons, C. C., Goodman, S. I., and Riley, C. M. (1967). Calcium carbimide in the treatment of primary hyperoxaluria. New Engl. f. Med., 276, 207.

Watts, R. W. E. (1960). The metabolic error in primary hyperoxaluria. M.D. Thesis, University of London.

Williams, H. E., Koch, J., and Smith, L. H., Jr. (1967). $L$-glyceric aciduria and glycolic aciduria: two genetic variants of primary hyperoxaluria. (Abstract.) f. clin. Invest., 46, 1133.

Wrong, O., and Davies, H. E. F. (1959). The excretion of acid in renal disease. Quart. F. Med., n.s. 28, 259. 